\title{
Неравновесные спиновые состояния и генерация терагерцового излучения в магнитных гетероструктурах
}

\author{
Е.А. Вилков ${ }^{1)}$, М.В. Логунов ${ }^{2)}$, С.А. Никитов ${ }^{2,3)}$, С.С. Сафонов ${ }^{2)}$, С.Г. Чигарев ${ }^{1)}$ \\ ${ }^{I}$ Фрязинский филиал Института радиотехники и электроники им. В. А. Котельникова РАН, \\ Фрязино, 125009, пл. Введенского, 1 \\ ${ }^{2}$ Институт радиотехники и электроники им. В. А. Котельникова РАН, \\ Москва, 125009, Моховая, 11/7 \\ ${ }^{3}$ Московский физико-технический институт (ГУ), Долгопрудный, 141701, Институтский пер., 9 \\ тел: +7 (495) 629-3465, эл. почта: logunov@cplire.ru
}

DOI 10.34077/RCSP2019-82

Магнитные гетероструктуры с протекающим по ним спин-поляризованным током являются одними из основных объектов исследований в спинтронике и спин-фотонике [1], что связано с перспективами многочисленных применений в терагерцовой спинтронике [2], трехмерных наномагнитных устройствах [3], запоминающих устройствах и сенсорах [4]. В таких гетероструктурах ток, протекающий в магнитном переходе, спин-поляризуется, что может приводить к значительному неравновесному накоплению спина в ограниченном объеме ферромагнитного материала. Спин-релаксационные переходы электронов проводимости между спиновыми подзонами ферромагнетика стимулированы опосредованно через $s d$-обменное взаимодействие с электромагнитной волной. Такие спин-флип переходы электронов могут сопровождаться испусканием или поглощением фотонов $[5,6]$ с частотой, определяемой энергией эффективного обменного расщепления спиновых подзон. Для ряда переходов энергия расщепления спиновых подзон соответствует энергии фотонов терагерцового диапазона частот, что представляет интерес с точки зрения применений гетероструктур как основы компактных терагерцовых источников излучения, в том числе работающих при комнатной температуре.

В докладе рассматривается зона проводимости ферромагнитного металла, обменно расщепленная на спиновые подзоны с некоторым энергетическим зазором [7, 8]. При этом зона проводимости считается неравновесной по спину из-за протекающих токов. Показано, что при инжекции спинов током из одного магнитного слоя (инжектора) в другой (рабочий слой) положение неравновесных квазиуровней Ферми (область частот излучения) определяется плотностью протекающего через магнитный контакт тока, углом рассогласования между направлением намагниченности инжектора и рабочего слоя, а также их равновесной спиновой поляризацией. Представлено уравнение динамики движения магнитного момента, усредненного по ансамблю неравновесных спин-инжектированных электронов в ферромагнитном переходе, с учетом обменного взаимодействия и взаимодействия с внешним электромагнитным полем, а также с термостатом. С использованием формализма матрицы плотности рассчитана скорость квантовых переходов электронов с противоположными направлениями спина, определяющих спиновую релаксацию при взаимодействии с термостатом. Обсуждаются модели терагерцовых источников излучения и влияние особенностей спин-флип переходов при релаксации магнитного момента на процессы испускания или поглощения фотонов с энергией, соответствующей энергии эффективного обменного расщепления спиновых подзон, а также возможности перестройки частоты спин-инжекционного излучения в терагерцовом диапазоне частот.

Работа выполнена при поддержке грантов РФФИ 18-52-16006, 18-29-27020.

\section{Лuтература}

[1] A. Fert, J.-M. George, H. Jaffrès et al. // Europhys. News. 2003. V. 34. P. 227.

[2] J. Walowski and M. Munzenberg. // J. Appl. Phys. 2016. V. 120. P. 140901.

[3] A. Fernandez-Pacheco, R. Streubel, O. Fruchart et al. // Nature Comm. 2017. V. 8. P. 15756.

[4] D. Sander, S. O. Valenzuela, D. Makarov et al. // J. Phys. D: Appl. Phys. 2017. V. 50. P. 363001.

[5] Ю. В. Гуляев, П. Е. Зильберман, И. В. Маликов и др. // Письма в ЖЭТФ. 2011. Т. 93. С. 289.

[6] V. Korenivski, A. Iovan, A. Kadigrobov, R. I. Shekhter. // Europhys. Lett. 2013. V. 104. P. 27011.

[7] Е. А. Вилков, Г. М. Михайлов, С. Г. Чигарев и др. // РЭ. 2016. Т. 61, № 9. С. 1-8.

[8] Е. А. Вилков, Г. М. Михайлов, С. А. Никитов и др. // ЖЭТФ. 2018. Т. 154. С. 1108. 